\title{
Nationwide and international registries on scleroderma. Past, present, and future
}

\author{
Manuel Rubio-Rivas* \\ Scleroderma and Sarcoidosis Section, Autoimmune Diseases Unit, Department of Internal Medicine, Hospital Universitario de Bellvitge-Instituto de \\ Investigación Biomédica de Bellvitge (IDIBELL), Barcelona, Spain
}

\begin{abstract}
Systemic sclerosis (SSc) is a low-incidence autoimmune disease that requires collaborative work through national or international registries to advance scientifically. The present systematic review aims to be an update of all national and international registries to date. In total, 7 first-world countries have SSc registries. In addition, there are also 3 international SSc registries plus 2 other registries focused on SSc-related pulmonary arterial hypertension. These registries not only carry out clinical research but also allow the collection of serum, DNA and tissue samples, as well as collaborative work to carry out randomized clinical trials and collaboration with other registries not directly focused on SSc.
\end{abstract}

Key words: Scleroderma. Systemic sclerosis. Registry.

\section{Introduction}

Scleroderma or systemic sclerosis (SSc) is an autoimmune disease that can be considered a rare disease because of its incidence. As such, it makes it difficult to study in an isolated research center. Many years of follow-up and dedication are needed to be able to gather a sufficient number of patients to be able to undertake research work that will allow valid knowledge to be obtained and extrapolated to other populations. World leadership during the second half of the $20^{\text {th }}$ century was held by large cohorts of a few centers such as the University of Pittsburgh ${ }^{1}$, the Johns Hopkins Hospital in Baltimore ${ }^{2}$, the University of Texas and Michigan $^{3}$, and the Royal Free Hospital in London ${ }^{4}$ or provincial/state registries such as the South Australian Scleroderma Register ${ }^{5}$. All of them, but especially the first one in the 1980s, were the seeds of what later became known as national or international registries. Today it is mandatory in a disease of low incidence, and the autoimmune ones would enter there too, to work based on a registry of these characteristics. In 2011, an attempt was made to update the existing registries $^{6}$, but it is clear that a decade later, we need to update them and see where we are heading in SSc research through the registries.

This study aimed to conduct an updated review of the different national or international registries on SSc, focusing on their similarities and differences.

\section{Methods}

For the present study, a systematic review of national and international registries in SSc has been carried out. The search was performed by reviewing the Medline

Visual abstract available at https://spanishjmed.com/frame_esp.php?id=48

$\begin{array}{llr}\text { Correspondence: } & \text { Date of reception: 04-01-2021 } & \text { Available online: 05-10-2021 } \\ \text { *Manuel Rubio-Rivas } & \text { Date of acceptance: 05-04-2021 } & \text { Span J Med. 2021;1(3):142-153 } \\ \text { E-mail: mrubio @ bellvitgehospital.cat } & \text { DOI: } 10.24875 / \text { SJMED.M21000011 } & \text { www.spanishjmed.com } \\ \text { 2696-5631 / @ 2021 Sociedad Española de Medicina Interna. Published by Permanyer. This is an open access article under the CC BY-NC-ND } \\ \text { license (http://creativecommons.org/licenses/by-nc-nd/4.0/). }\end{array}$




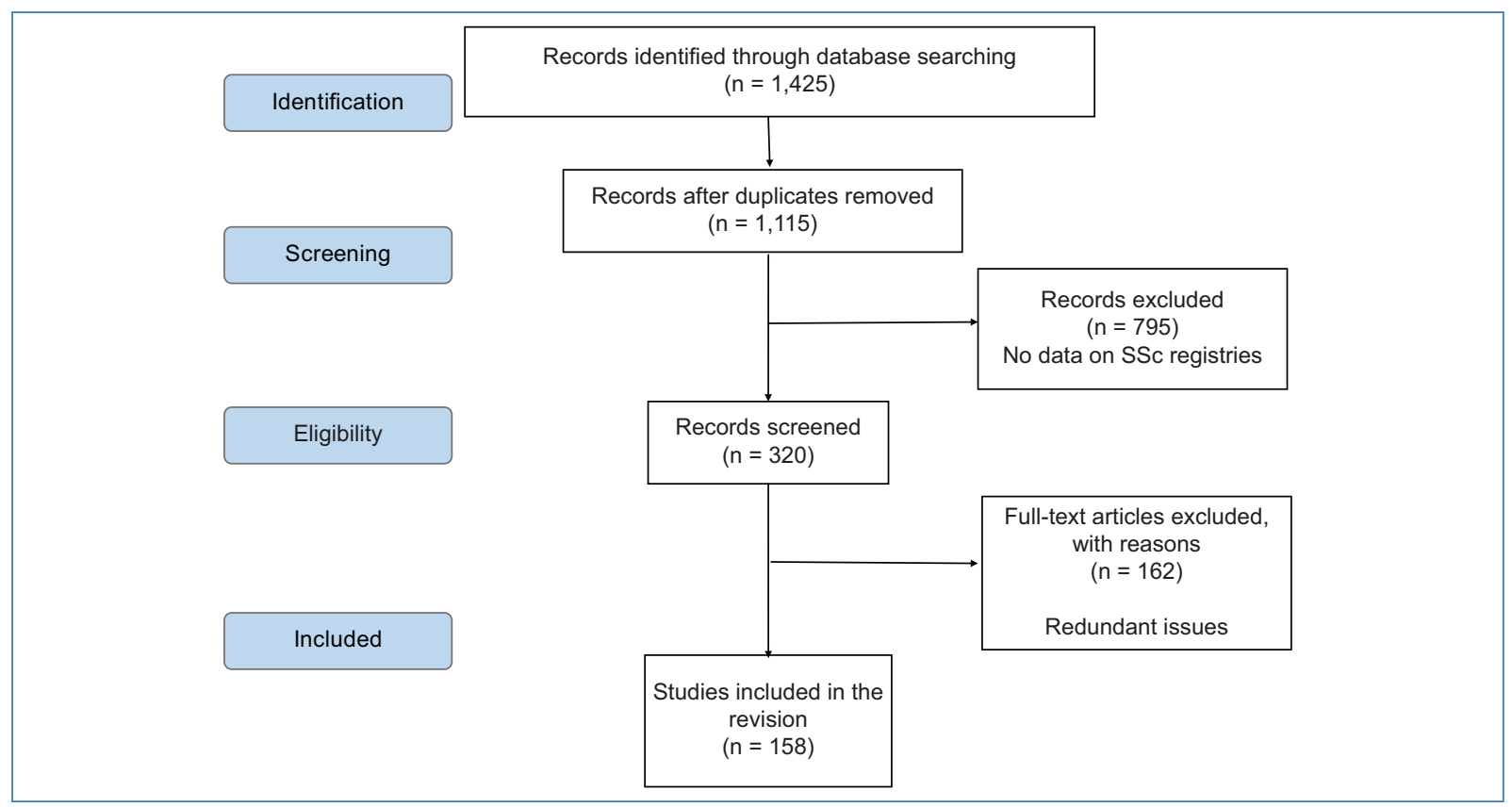

Figure 1. PRISMA 2009 flow diagram.

database following the terms ("Scleroderma, Systemic" [Mesh]) AND "Registries" [Mesh]). Besides, the medical bibliography of the medical coordinator of each of the registries was reviewed as well as a search following the name of the registry on PubMed and the webpage (when available) of the registry (Fig. 1). Not all registries present their data in the same way and at the same time. Thus, the data included in the supplementary tables are indicative and correspond in some cases to the paper of presentation of the registry and, in others, to one of the following papers (Suppl. Tables 1 and 2 and Figs. 2 and 3).

\section{Results}

\section{Scleroderma registries}

UK, 1995

The UK Scleroderma Study Group (UKSSG) is a working group of key centers that have a clinical and research interest in SSc and have worked collaboratively to promote research and clinical practice in SSc patients over the past 25 years. The group was established by Professor Dame Carol Black on the principle of inclusive participation. A national registry in the United Kingdom, initiated in 1995, includes details of 37 centers of SSc and contains data on $>2500$ patients. It allows the collection of blood samples for DNA, serum, plasma, and skin biopsies. It also links to systematic databases maintained on pulmonary arterial hypertension (PAH) and interstitial lung disease (ILD).

The UKSSG, mostly centered in the Royal Free Hospital in London, has enabled the study and development of management guidelines in renal ${ }^{7}$ and gastrointestinal involvement ${ }^{8}$ and in the management of digital ulcers $(\mathrm{DU})^{9}$. It has also deepened the study and management of PAH and ILD ${ }^{10-12}$. It has also made advances in the treatment of diffuse forms of the disease ${ }^{13,14}$ and the study of RNA pol III patients ${ }^{15}$.

The head office is at the Royal Free Hospital in London and is headed by Dr. C. Denton.

\section{GeRMANY, 2003}

The German Network for Systemic Scleroderma (DNSS) was founded in 2003 with a grant from the German Federal Ministry of Education and Research. There is an intense collaboration of different subspecialties, including dermatologists, rheumatologists, pulmonologists, and nephrologists. Like the other registries, it includes socio-demographic, clinical, laboratory, and follow-up data. DNSS maintains a centralized online patient registry that includes all SSc patient data on a standardized four-page DNSS questionnaire. The network also provides the infrastructure for collecting blood and tissue samples. It now gathers data from more than 3000 patients from over 40 centers. 


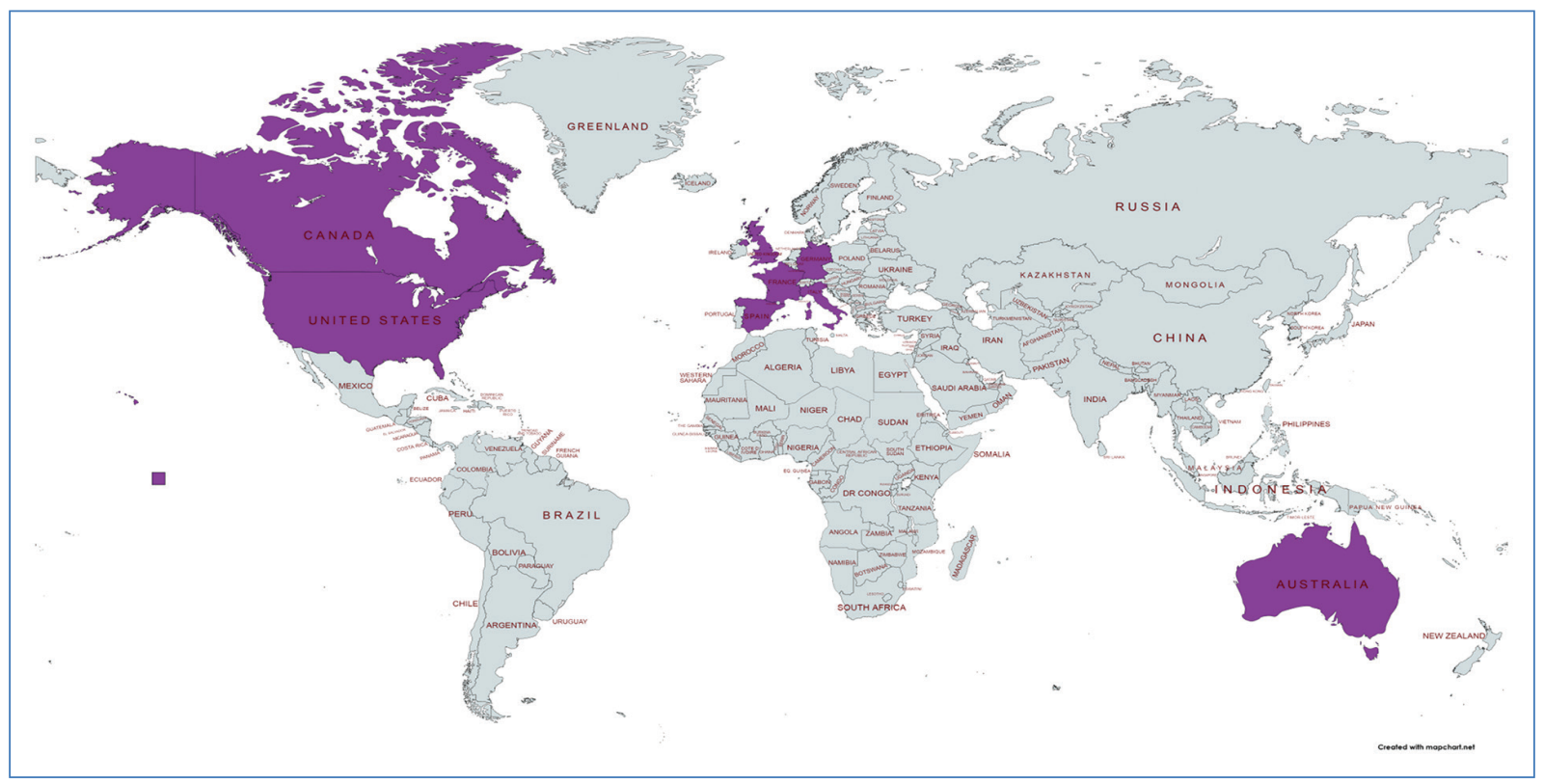

Figure 2. Map chart of the national systemic sclerosis registries.

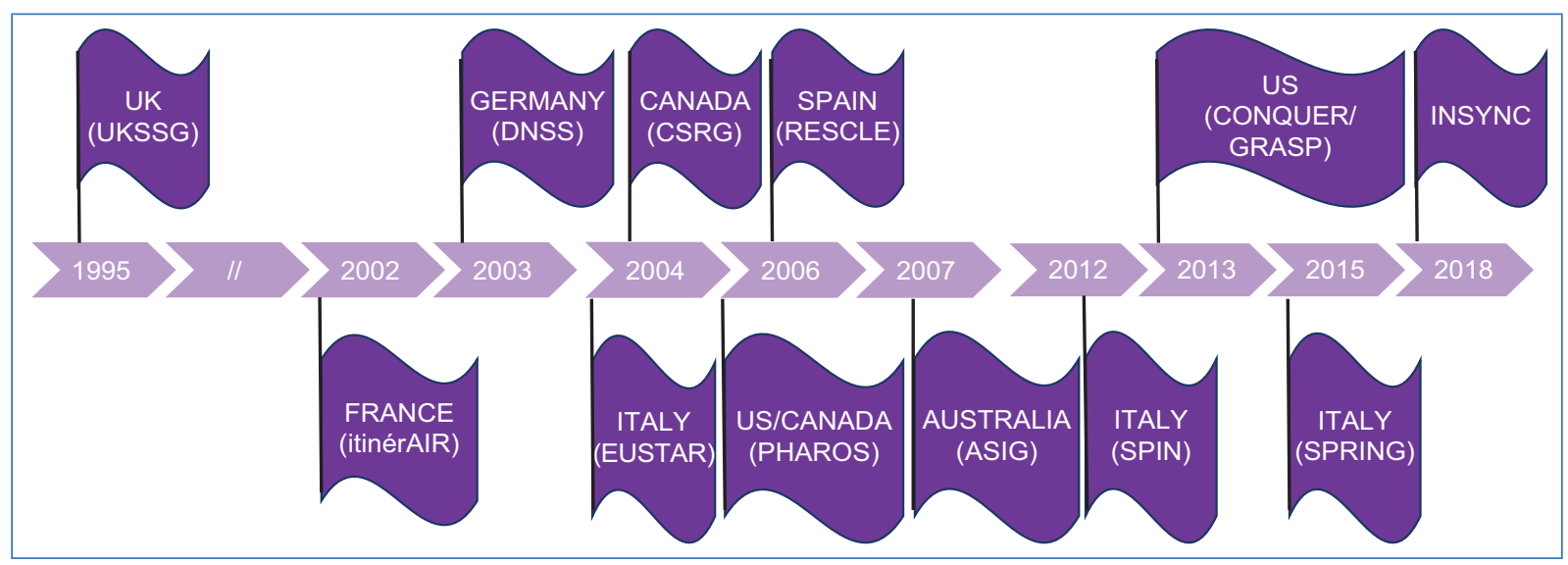

Figure 3. Timeline of the national systemic sclerosis registries over time.

The German registry has firstly served to characterize German patients with $\mathrm{SSc}^{16}$. It has provided advances in the correlation of cutaneous and visceral involvement as well as in the management of cutaneous vascular complications ${ }^{17-20}$. It has also served to immunologically characterize German patients on a national level ${ }^{21}$. It has also deepened the knowledge and prognostic evaluation of patients with overlap syndrome ${ }^{22}$ and late-onset $\mathrm{SSc}^{23}$ and the excessive use of corticosteroids and immunosuppressants in patients with $\mathrm{SSc}^{24}$.
The Central Coordination Office was established at the Department of Dermatology and Venereology at the University of Cologne and acts as a data manager. It is directed by Dr. N. Hunzelmann.

\section{EUSTAR, 2004}

The EULAR Scleroderma Trials and Research Group (EUSTAR) was founded in 2004 at the University Hospital of Florence (Italy) with the support of a EULAR research grant under the chairmanship of 
Marco Matucci. To promote awareness, understanding, and research into SSc and its care and treatment throughout Europe, the EUSTAR group was launched under the auspices of the EULAR standing committee on international clinical trials involving therapeutic trials (ESCISIT) and a prospective multicenter cohort of SSc was established. EUSTAR was initiated in 2003 and the SSc database was launched in 2004. It represents a multinational, prospective, and open SSc cohort. Participating centers enter the minimum essential data set (MEDS) with all consecutive consent patients who meet the ACR classification criteria for SSc. The MEDS was designed by consensus by EUSTAR members and covers demographics, disease duration, organ involvement, and laboratory data. Annual follow-up examinations are conducted. To improve long-term data analysis and follow-up of patients suitable for clinical and basic research trials, an online database (MEDS Online) was launched in June $2006^{25}$. Simultaneously, the MEDS was expanded with features such as right heart catheter measurements, medication, and a center-based biobank, which collects sera, tissue samples, and DNA material. To date, more than 11,000 patients from 234 centers are included in the study.

EUSTAR has been a constant source of recommendations in management, research, and biobanking strategies in $\mathrm{SSc}^{26-30}$. It has also contributed to the improvement of the clinical assessment of organic manifestations and the implementation of the modified Rodnan skin score and organic damage ${ }^{31,32}$. It has allowed the characterization of different geographical regions ${ }^{33}$ and the study of differences between races ${ }^{34}$. It has made advances in the study of disability ${ }^{35}$, cutaneous involvement ${ }^{36,37}$, articular ${ }^{38,39}$, vascular ${ }^{40-42}$, cardiac $^{43}$, pulmonary, ${ }^{44-47}$ and digestive involvement ${ }^{48,49}$, also the identification of phenotypic clusters in $\mathrm{SSc}^{50}$. It has also made advances in the study of different subpopulations such as patients with young and late-onset $\mathrm{SSc}^{51,52}$, early and very early $\mathrm{SSc}^{53-55}$, also in those patients with antitopoisomerase I anti-bodies (ATA), anticentromere antibodies (ACA), anti-Ku, PM-Scl, RNA pol III antibodies, and in those antinuclear antibody (ANA) negative ${ }^{56-60}$. It has also contributed to the study of risk factors, including 2 prognostic scores ${ }^{61-66}$. It has finally conducted studies to assess the efficacy of tocilizumab, abatacept, rituximab, cyclophosphamide, and hydroxychloroquine in different subpopulations ${ }^{67-71}$.

The current data center is located at the University Hospital of Zurich and is directed by Dr. O. Distler.

\section{CANADA, 2004}

In 2003, a group of 17 rheumatologists from across Canada met and recognized the need to unite to better treat patients with SSc. The Scleroderma Research Group of Canada (CSRG) is a multicenter research cohort established in 2004. The CSRG has been made possible by grants from the Canadian Institutes for Health Research, private donations, Scleroderma Canada, all provincial scleroderma patient groups, the Scleroderma Healing Foundation, as well as several Canadian pharmaceutical companies. At present, the patient registry contains detailed longitudinal clinical data on over 1750 patients from 15 different sites, plus a biobank of samples.

The Canadian registry (CSRG) has been very prolific since its inception. It has focused on the study of quality of life $^{72}$, fatigue ${ }^{73}$, frailty ${ }^{74}$, pain ${ }^{75}$, sleep disturbances ${ }^{76}$, depression ${ }^{77}$, malnutrition ${ }^{78}$, work disability ${ }^{79}$, self-reported physical health ${ }^{80}$, oral health ${ }^{81}$, SSc-associated cancer ${ }^{82}$, sexual activity ${ }^{83}$, the impact of socioeconomic status ${ }^{84}$, and the cost of $\mathrm{SSc}^{85}$. It has also made advances in the immunological characterization of patients with SSc and its clinical implications, especially in those patients with antifibrillarin anti-bodies, ACA, Ro52, PM/Scl, TRIM 21, $\mathrm{Th} / \mathrm{To}, \mathrm{Ku}$, and HMGCR${ }^{86-93}$, also those patients with negative $\mathrm{ANA}^{94}$. Knowledge of visceral gastrointestinal $^{95-97}$, pulmonary ${ }^{98-100}$, renal ${ }^{101}$, muscular ${ }^{102}$, cutaneous ${ }^{103}$, and vascular involvement ${ }^{104}$ has also improved. It has also provided knowledge in aspects of the diagnosis of the disease $\mathrm{e}^{105}$ and in the assessment of organ damage $^{106}$. It has also served to characterize a Native North American population with $\mathrm{SSc}^{107}$. Finally, it has furthered the study of a large subpopulation of patients with scleroderma sine scleroderma ${ }^{108}$.

The head office is located at the Jewish General Hospital in Montreal and is headed by Dr. M. Baron and K. McKenna.

\section{SPAIN, 2006}

The Spanish Registry of Scleroderma (RESCLE) was created by the Autoimmune Systemic Disease Group (GEAS) of the Spanish Society of Internal Medicine in 2006 to compile a wide range of Spanish patients with SSc. At that time, there were 14 participating centers; today, there are 40 centers throughout the country. Thus, until 2006 the data were collected retrospectively and since 2006 (or the date of inclusion of a new center), it has been done prospectively. Epidemiological, clinical, laboratory, capillary, and immunological data covering 
267 variables are included in the database. Annual follow-up examinations are conducted.

The Spanish scleroderma registry has not only characterized the Spanish population with $\mathrm{SSc}^{109}$ but has also made advances in the characterization of liver involvement ${ }^{110}$, vascular ${ }^{111}, \operatorname{ILD}^{112}$, and $\mathrm{PAH}^{113}$, as well as the role of phosphodiesterase inhibitors and endothelin receptor antagonists as bi-therapies in the prognosis of PAH versus monotherapy ${ }^{114}$. The preventive role of these drugs in the development of $\mathrm{PAH}$ and the renal crisis has also been evaluated ${ }^{115}$. The registry has furthered the study of the immunological profile and, in particular, the study of serodiscordant patients with the cutaneous subtype ${ }^{116,117}$. It has also studied the subpopulation with early and very early $\mathrm{SSc}^{118}$, as well as deepened into the causes of death and their change over time ${ }^{119,120}$. It has identified new risk factors and created a new long-term prognostic tool ${ }^{121,122}$.

There is no registry-associated biobank to store evidence. To date, collects data from 2,238 patients. The central database coordinator and administrator is $\mathrm{S} \& \mathrm{H}$ Medical Science Service and medical coordination is directed by Dr. C.P. Simeón and V. Fonollosa from Vall d'Hebron University Hospital in Barcelona.

\section{Australia, 2007}

The Steering Committee of the Scleroderma Interest Group of Australia (Australian Scleroderma Interest Group [ASIG]) met for the $1^{\text {st }}$ time in November 2005 and in 2007 became a special interest group under the auspices of the Australian Rheumatology Association, a non-profit organization incorporated as a corporation in Australia. The ASIG is a multidisciplinary collaboration of rheumatologists, immunologists, cardiologists, and respiratory physicians from across Australia with a special interest in improving outcomes for patients with SSc and mixed connective tissue disease. In 2007, ASIG established the Australian Scleroderma Cohort Study (ASCS), using a web-based platform to detect the cardiac and pulmonary complications of these diseases as a service to patients with SSc and their rheumatologists. The main goal of the ASCS is to improve clinical care by increasing the rate of detection of SSc-related PAH and ILD to enable earlier identification of high-risk patients and the institution of timely treatment. Blood samples are collected and processed at most centers and transferred to Adelaide for storage in the ASIG blood biobank. All members of the ASIG are clinical rheumatologists. To date, over 1600 patients from 13 centers are included in the registry.
The ASIG registry has contributed to the field of PAH screening ${ }^{123,124}, \mathrm{Gl}$ involvement ${ }^{125}$, overlap syndrome ${ }^{126}$, quality of life ${ }^{127}$, and activity impairment ${ }^{128}$. Furthermore, in the immunological characterization of patients, especially patients with anti-Ku, anti-RNA pol III, and anti-PM75-100 ${ }^{86,129-130}$, also the relation with occupational silica exposure ${ }^{131}$.

The project coordinator and database administrator for ASIG were appointed in 2006 and is based in the Department of Rheumatology at St. Vincent's Hospital in Melbourne. It is directed by Dr. S. Proudmann and M. Nikpour.

\section{Scleroderma Patient-centered Intervention NETWORK (SPIN), 2012}

The SPIN, an international collaboration of patient organizations, clinicians, and researchers, was recently organized and funded by the Canadian Institutes of Health Research. The long-term goals of SPIN are to develop, test, and disseminate accessible interventions to complement standard medical care and improve outcomes in SSc. The SPIN uses a novel research design, the Multiple Cohort Randomized clinical trial Design, to collect longitudinal data related to the problems experienced by people living with SSc and as a framework for the development, evaluation, and delivery of psychosocial and rehabilitation interventions. The first step toward the long-term objectives of the SPIN is the establishment of the SPIN Cohort ${ }^{131}$. It does not have an associated biobank. By 2020, more than 1700 patients have been recruited from 43 centers in Canada, the USA, UK, France, Spain, Mexico, and Australia.

The SPIN cohort has furthered the study of physical activity $^{132}$, physical and occupational therapy ${ }^{133}$, hand function ${ }^{134}$, and online self-care intervention in patients with $\mathrm{SSc}^{135}$. It has also made advances in the evaluation of mental health in the SSc population, recently also concerning COVID-19136,137.

The SPIN is led by Dr. B. Thombs of the Jewish General Hospital and McGill University in Montreal, Canada.

\section{THE US, THE CONQUER REgISTRY, 2013}

In 2011, the Prospective Registry of Early SSc (PRESS) was developed in the US in response to FDA and $\mathrm{NIH}$ calls for attention to Therapeutics for Rare and Neglected Diseases and developing tissue banks linked to clinical outcomes. PRESS researchers were contacted by the Scleroderma Research Foundation 
(SRF) to build on their efforts. The overall goal of the SRF partnership with participating academic Scleroderma Centers is to accumulate the largest possible cohort of early-stage scleroderma patients. This highly collaborative effort, initially among 12 of the largest SSc centers in the United States, has been named CONQUER (an acronym for COllaborative, National QUality and Efficacy Registry for Tracking Disease Progression in SSc [scleroderma] Patients). The CONQUER Registry was developed in 2013. The SRF is a non-profit organization based in San Francisco. It is the nation's leading non-profit investor in medical research and its mission is to fund and facilitate the most promising and highest quality research aimed at improving therapies and ultimately curing scleroderma. The SRF has established strategic partnerships with several other sponsors who are providing financial and other support elements to ensure the success of the CONQUER Registry, in special Boehringer Ingelheim and Actelion laboratories. The Biorepository Center at The University of Texas Health Science Center at Houston will provide processing, storage, and management services for CONQUER Registry members, as it does for a variety of national research networks. The registry includes 12 SSc centers geographically distributed throughout the U.S., including California, Texas, Utah, Illinois, Michigan, Massachusetts, Maryland, New York, South Carolina, and Washington, D.C.

The CONQUER register has only published its initial set-up with baseline data from its longitudinal cohort ${ }^{138}$.

The data center is based at the University of Utah, and the biospecimen repository is located at the University of Texas Health Science Center in Houston.

\section{THE US, THE GRASP REGISTRY, 2013}

The African American Scleroderma Genome Research Project (GRASP) was established to improve our understanding of the clinical manifestations of SSC in African Americans and to conduct genomic analyses to identify key factors contributing to the occurrence and severity of their disease. To achieve these goals, a large cohort of African-American patients with SSc has been assembled and clinical data and DNA samples have been collected from all enrolled patients. The GRASP clinical database was established in 2013 and includes the sociodemographic and clinical characteristics of a U.S. cohort of exclusively African-American SSc patients enrolled retrospectively and prospectively over 30 years (1987-2016). African-American race was determined by patient self-identification. The GRASP consortium was supported by research funding from the SRF and the Intramural Research Programs of the National Human Genome Research Institute and the National Institute of Arthritis and Musculoskeletal and Skin Diseases. The GRASP cohort currently consists of more than 1,200 extensively evaluated African-American SSc patients enrolled at 23 participating academic centers in the United States. This is the largest multicenter cohort of African American patients with SSc ever studied.

The GRASP cohort has published only its baseline data in which it characterizes the largest Afro-American SSc cohort described to date ${ }^{139}$.

The data center is based at the Johns Hopkins University coordination site and is led by Dr. F. Wigley and F. Boin.

\section{ITALY, 2015}

The SPRING is the last national registration to date. It was promoted by the Italian Society of Rheumatology in 2015. Study data were collected and managed using REDCap, electronic data capture tools hosted by SIR REDCap (Research Electronic Data Capture), which is a secure web-based application designed to support data capture for research studies. Patients were screened consecutively and enrolled at each participating center according to standardized study procedures. All patients were hierarchically classified into 4 different cohorts: (1) primary Raynaud's phenomenon (RP); (2) suspected secondary RP; (3) very early diagnosis of SSc (VEDOSS); (4) definitive SSc according to ACR/ EULAR 2013 classification criteria for SSc. A biobank associated with the registry is not available to store evidence. To date, it includes more than 1700 patients from 38 centers.

Still, in its early days, the SPRING has served to characterize the Italian population with $\mathrm{SSc}^{140}$.

The SPRING is led by Dr. C Ferri of the University of Modena and M Matucci of the University of Florence.

\section{INSYNC, 2018}

In 2018, the International SSc Initiation Cohort (INSYNC) pooled data from the ASCS, the cohort study of the Canadian Scleroderma Research Group (CSRG), the Leiden SSc cohort (Leiden CCIS cohort), Spain (the scleroderma cohort of the University Hospital 12 de Octubre in Madrid), and Sweden (the SSc cohort of the Rheumatology Unit of the Skane University Hospital, Lund). Here, data from national registries and cohorts from a single-center are combined. To date, INSYNC 
includes sites in Canada, Australia, the Netherlands, Spain, Germany, Brazil, the United States, and Sweden. It should be noted that INSYNC relies entirely on the infrastructure of the CSRG for administrative and statistical support.

Still, in its early days, the INSYNC cohort has advanced the assessment of the health-related quality of life in patients with $\mathrm{SSc}^{141}$.

It currently has more than 600 patients from 31 centers. It does not have a biobank.

\section{Registries focused on SSc-related PAH}

\section{France, ItinÉrAIR-SCLÉROderMIE, 2002}

The ItinérAIR-Sclérodermie Investigators Group was established in 2002 to prospectively collect patients with SSc and group I PAH. The ItinérAIR-Sclérodermie registry includes data on 599 patients diagnosed with SSc. It has made advances in the diagnostic algorithm of PAH and its early detection ${ }^{142}$. It has also served to study the prevalence and incidence of PAH in a SSC population ${ }^{143,144}$, as well as survival and risk factors for poor prognosis ${ }^{145-147}$.

The registry is run by ACTELIONPHARMACEUTICALS FRANCE, SAS and is headed by Dr. M. Humbert.

\section{US/CANADA, PHAROS, 2006}

The Pulmonary Hypertension Assessment and Recognition of Outcomes in Scleroderma (PHAROS) Registry is a prospective multicenter study in compliance with the US Health Insurance Portability and Accountability Act (HIPAA) conducted at 19 US and Canadian sites. There were two patient populations enrolled in the registry: patients with SSc at risk for $\mathrm{PAH}$ and those with incident PAH. At-risk patient enrollment criteria were: (1) DLCO $<55 \%$ predicted with an FVC of $>70 \%$ predicted; (2) FVC/DLCO ratio $>1.6$; or (3) estimated right ventricular systolic pressure $>40 \mathrm{~mm} \mathrm{Hg}$ on ECG. At-risk patients underwent PAH screening annually or sooner if clinically indicated. Right heart catheterization (RHC) was performed for at-risk patients based on clinical indication during follow-up. Patients with incident PAH were diagnosed by $\mathrm{RHC}$ within 6 months of enrollment ${ }^{148}$.

The PHAROS registry has allowed the study of risk factors in a subpopulation at risk of $\mathrm{PAH}$ and in a population already diagnosed with $\mathrm{PAH}^{149-151}$. It has also contributed to the hemodynamic study of these patients $^{152,153}$, the prognostic role of related antibodies, and biomarkers ${ }^{154,155}$, the influence of ILD in these patients ${ }^{156}$, and the response to oral therapy ${ }^{157}$.

This is being coordinated by Dr. V. Steen at Georgetown University (Washington DC).

\section{Discussion}

The University of Pittsburgh Scleroderma Databank was the first SSc registry initiated in 1980. Although it has always functioned as a reference center in the US, it is still a single-center and, therefore, far from the objective of the present review. It is the prototype of all registries in SSc as it includes a comprehensive initial evaluation, standard SSc examination, laboratory studies, and yearly serum and DNA samples. Most importantly, it includes a comprehensive annual to biannual follow-up of patients. This databank now has $>4000$ patients with $>30$ years of follow-up data.

The path of clinical research in SSc has been through national registries. It has opened up possibilities unimaginable in the last century for most centers and has increased clinical knowledge of the disease. It has allowed better characterization of patients and improved knowledge of prognostic factors of the disease. We owe this luck firstly to the world reference center in Pittsburgh and its researchers and secondly to the researchers promoting the different registries in each of these countries mentioned above. In short, we are talking about 7 countries, not many, but they give a good account of what SSc is, at least in the first world (Suppl. Tables 1 and 2 and Figs. 2 and 3). Unfortunately, we do not have national registries in $3^{\text {rd }}$ world countries or in developing or emerging countries. We do not have national data from Asia or Africa either. In general, national registries cover the entire spectrum of the disease, although the ASIG is mainly focused on pulmonary manifestations (PAH and ILD). In recent years, supranational initiatives have appeared, first with EUSTAR and later with SPIN and INSYNC. The case of the SPIN is special because it is specifically designed to perform randomized clinical trials, it opens a door to a different type of systematic collaboration between various working groups.

If the same disease has already benefited from this large amount of data included in the same registry despite its low incidence, it has been even more important to study certain clinical manifestations that only a small group of patients suffer. This is where PAH, ILD, and scleroderma renal crisis (SRC) would come in. The study of these continues to be difficult due to the limitation in the number of patients who suffer from it, but 
it is no longer impossible. Furthermore, it allows the isolated study of these clinical manifestations in a homogeneous group of patients with SSc and not included in studies with other types of patients as occurs, for example, in studies of PAH including patients with idiopathic PAH and other subtypes. In this regard, several national registries dedicated to the study of pulmonary hypertension have emerged in recent decades. Two of them have focused on SSc-related $\mathrm{PAH}$, such as the ItinerAIR-Sclérodermie registry and the PHAROS registry (Suppl. Tables 3 and 4 and Figs. 1 and 2). They are cohorts of patients with incident PAH patients and patients not yet diagnosed with $\mathrm{PAH}$. The inclusion of patients without PAH is broader in the former, so the incidence of PAH in the French cohort is lower. These cohorts allow a more rigorous study of this organic condition but they need years to be able to gather a sufficient number of patients to allow their study given their low incidence. There are no similar registries for SSc-related ILD or SRC.

On the other hand, the limitations inherent in these registries have to be commented on. First, as in all multicenter studies, there is heterogeneity between centers in terms of knowledge of the disease, management. The constant feedback from scientific meetings minimizes these differences, but they are there. Second, they are databases with several predefined variables and not designed for a specific study. This sometimes limits the study in depth of a specific topic that requires data not present in the database. Third, the management of the SSc overlaps between several specialties, mainly Internal Medicine and Rheumatology, Dermatology, Pneumology, among others. The registries are usually endorsed on occasions by a single scientific society so that certain patients may not be represented in the registry and this could lead to a bias toward inclusion. Fourth, it is important that a registry has reference centers in SSc but also $2^{\text {nd }}$ and $3^{\text {rd }}$ level centers without so much experience in its management. This may not occur in all registries and the big picture of the SSc in that country would not faithfully reflect the real seriousness of the patients. Fifth, most of the registries are prospective, but not all. A registry with retrospective data runs the risk of committing an inclusion bias. If a rigorous search has not been carried out to include previously deceased patients, it will only be including patients who have arrived alive at the time of recruitment and therefore those patients with severe SSc and risk factors of bad outcomes will be minimized in oblivion. Besides, the information in retrospect is not always available and this leads to loss of information in the registry.

In conclusion, the registries have shown their benefits in terms of progress in knowledge, and in a few years and with a greater follow-up of patients will be able to continue providing very interesting data from which we will learn even more. We can see that this type of research can have a limit and we should think about going further. Some of these registries include blood and tissue biobanks. This opens the door to new lines of research not possible until now. International cooperation is increasingly common and some of the latest registries have been born on this basis. Finally, registries are the basis of many observational studies, but the example of the SPIN shows the possibility of conducting clinical trials on a cooperative and systematic international basis. All this is good news for a disease like SSc, orphaned in the last century and of which we know more every day that passes. Our patients will be grateful for it.

\section{Funding}

This research did not receive any specific grant from funding agencies in the public, commercial, or not-forprofit sectors.

\section{Conflicts of interest}

The authors declare that they have no conflicts of interest.

\section{Ethical disclosures}

Protection of human and animal subjects. The authors declare that no experiments were performed on humans or animals for this study.

Confidentiality of data. The authors declare that no patient data appear in this article.

Right to privacy and informed consent. The authors declare that no patient data appear in this article.

\section{Supplementary data}

Supplementary data are available at Spanish Journal of Medicine online (www.spanishjmed.com). These data are provided by the corresponding author and published online for the benefit of the reader. The contents of supplementary data are the sole author's responsability. 


\section{References}

1. Steen VD, Powell D, Medsger TA Jr. Clinical correlations and prognosis based on serum autoantibodies in patients with systemic sclerosis. Arthritis Rheum. 1988;31:196-203.

2. Greidinger EL, Flaherty KT, White B, Rosen A, Wigley FM, Wise RA. African-American race and antibodies to topoisomerase I are associated with increased severity of scleroderma lung disease. Chest. 1998;114:801-7.

3. Mayes MD, Lacey JV, Beebe-Dimmer J, Gillespie BW, Cooper B Laing TJ, et al. Prevalence, incidence, survival, and disease characteristics of systemic sclerosis in a large US population. Arthritis Rheum. 2003;48:2246-55.

4. Black CM. Scleroderma--clinical aspects. J Intern Med. 1993;234:115-8.

5. Chandran G, Ahern MJ, Smith M, Roberts-Thomson PJ. A study of scleroderrna in South Australia: prevalence, subset characteristics and nailfold capillaroscopy. Aust NZ J Med. 1995;25:688-94.

6. Galluccio F, Walker UA, Nihtyanova S, Moinzadeh P, Hunzelmann N, Krieg T, et al. Registries in systemic sclerosis: a worldwide experience. Rheumatology. 2011;50:60-8.

7. Lynch BM, Stern EP, Ong V, Harber M, Burns A, Denton CP. UK scleroderma study group (UKSSG) guidelines on the diagnosis and management of scleroderma renal crisis. Clin Exp Rheumatol. 2016;34 Suppl 100:106-9.

8. Thoua NM, Bunce C, Brough G, Forbes A, Emmanuel AV, Denton CP. Assessment of gastrointestinal symptoms in patients with systemic sclerosis in a UK tertiary referral centre. Rheumatology (Oxford). 2010;49:1770-5

9. Hughes M, Ong VH, Anderson ME, Hall F, Moinzadeh P, Griffiths B, et al. Consensus best practice pathway of the UK scleroderma study group: digital vasculopathy in systemic sclerosis. Rheumatology (Oxford). 2015;54:2015-24

10. Denton $\mathrm{CP}$, Humbert M, Rubin L, Black CM. Bosentan treatment for pulmonary arterial hypertension related to connective tissue disease: a subgroup analysis of the pivotal clinical trials and their open-label extensions. Ann Rheum Dis. 2006;65:1336-40.

11. Williams MH, Handler CE, Akram R, Smith CJ, Das C, Smee J, et al. Role of $\mathrm{N}$-terminal brain natriuretic peptide (N-TproBNP) in scleroderma-associated pulmonary arterial hypertension. Eur Heart J. 2006;27:1485-94

12. Hoyles RK, Ellis RW, Wellsbury J, Lees B, Newlands P, Goh NS, et al A multicenter, prospective, randomized, double-blind, placebo-controlled trial of corticosteroids and intravenous cyclophosphamide followed by ora azathioprine for the treatment of pulmonary fibrosis in scleroderma. Arthritis Rheum. 2006;54:3962-70

13. Herrick AL, Lunt M, Whidby N, Ennis $\mathrm{H}$, Silman A, McHugh N, et al. Observational study of treatment outcome in early diffuse cutaneous systemic sclerosis. J Rheumatol. 2010;37:116-24.

14. Nihtyanova SI, Brough GM, Black CM, Denton CP. Mycophenolate mofetil in diffuse cutaneous systemic sclerosis--a retrospective analysis. Rheumatology (Oxford). 2007;46:442-5.

15. Nihtyanova SI, Parker JC, Black CM, Bunn CC, Denton CP. A longitudinal study of anti-RNA polymerase III antibody levels in systemic sclerosis. Rheumatology (Oxford). 2009;48:1218-21.

16. Hunzelmann N, Genth E, Krieg T, Lehmacher W, Melchers I, Meurer M, et al. The registry of the German Network for Systemic Scleroderma: frequency of disease subsets and patterns of organ involvement. Rheumatology. 2008;47:1185-92.

17. Hanitsch LG, Burmester GR, Witt C, Hunzelmann N, Genth E, Krieg T, et al. Skin sclerosis is only of limited value to identify SSc patients with severe manifestations--an analysis of a distinct patient subgroup of the German systemic sclerosis network (DNSS) register. Rheumatology (Oxford). 2009;48:70-3.

18. Herrgott I, Riemekasten G, Hunzelmann N, Sunderkötter C. Managemen of cutaneous vascular complications in systemic scleroderma: experience from the German network. Rheumatol Int. 2008;28:1023-9.

19. Sunderkötter C, Herrgott I, Brückner C, Moinzadeh P, Pfeiffer C, Gerss J, et al. Comparison of patients with and without digital ulcers in systemic sclerosis: detection of possible risk factors. Br J Dermatol. 2009;160:835-43.

20. Moinzadeh P, Riemekasten G, Siegert E, Fierlbeck G, Henes J, Blank N, et al. Vasoactive therapy in systemic sclerosis: real-life therapeutic practice in more than 3000 patients. J Rheumatol. 2016;43:66-74

21. Mierau R, Moinzadeh P, Riemekasten G, Melchers I, Meurer M, Reichenberger $\mathrm{F}$, et al. Frequency of disease-associated and other nuclear autoantibodies in patients of the German network for systemic scleroderma: correlation with characteristic clinical features. Arthritis Res Ther. 2011;13:R172.

22. Moinzadeh $\mathrm{P}$, Aberer $\mathrm{E}$, Ahmadi-Simab $\mathrm{K}$, Blank $\mathrm{N}$, Distler $\mathrm{JH}$ Fierlbeck G, et al. Disease progression in systemic sclerosis-overlap syndrome is significantly different from limited and diffuse cutaneous systemic sclerosis. Ann Rheum Dis. 2015;74:730-7.

23. Moinzadeh P, Kuhr K, Siegert E, Mueller-Ladner U, Riemekasten G, Günther $\mathrm{C}$, et al. Older age onset of systemic sclerosis accelerated disease progression in all disease subsets. Rheumatology (Oxford). 2020;59(11):3380-9.
24. Hunzelmann N, Moinzadeh $P$, Genth E, Krieg T, Lehmacher W, Melchers I, et al. High frequency of corticosteroid and immunosuppressive therapy in patients with systemic sclerosis despite limited evidence for efficacy. Arthritis Res Ther. 2009;11:R30.

25. Tyndall A, Mueller-Ladner U, Matucci-Cerinic M. Systemic sclerosis in Europe: first report from the EULAR Scleroderma Trials and Research (EUSTAR) group database. Ann Rheum Dis. 2005:64:1107.

26. Avouac J, Kowal-Bielecka O, Landewe R, Chwiesko S, Miniati I, Czirjak L, et al. European league against rheumatism (EULAR) scleroderma trial and research group (EUSTAR) recommendations for the treatment of systemic sclerosis: methods of elaboration and results of systematic literature research. Ann Rheum Dis. 2009;68:629-34.

27. Kowal-Bielecka O, Fransen J, Avouac J, Becker M, Kulak A, Allanore Y, et al. Update of EULAR recommendations for the treatment of systemic sclerosis. Ann Rheum Dis. 2017;76:1327-39.

28. Hoffmann-Vold AM, Distler O, Murray B, Kowal-Bielecka O, Khanna D, Allanore $Y$, et al. Setting the international standard for longitudinal follow-up of patients with systemic sclerosis: a Delphi-based expert consensus on core clinical features. RMD Open. 2019;5:e000826.

29. Tyndall A, Ladner UM, Matucci-Cerinic M. The EULAR scleroderma trials and research group (EUSTAR): an international framework for accelerating scleroderma research. Curr Opin Rheumatol. 2008;20:703-6.

30. Beyer C, Distler JH, Allanore Y, Aringer M, Avouac J, Czirják L, et al. EUSTAR biobanking: recommendations for the collection, storage and distribution of biospecimens in scleroderma research. Ann Rheum Dis. 2011;70:1178-82.

31. Walker UA, Tyndall A, Cziriák L, Denton C, Farge-Bancel D, Kowal-Bielecka $\mathrm{O}$, et al. Clinical risk assessment of organ manifestations in systemic sclerosis: a report from the EULAR scleroderma trials and research group database. Ann Rheum Dis. 2007;66:754-63.

32. Czirják L, Nagy Z, Aringer M, Riemekasten G, Matucci-Cerinic M, Furst DE, et al. The EUSTAR model for teaching and implementing the modified Rodnan skin score in systemic sclerosis. Ann Rheum Dis. 2007;66:966-9.

33. Walker UA, Tyndall A, Czirják L, Denton CP, Farge-Bancel D, Kowal-Bielecka O, et al. Geographical variation of disease manifestations in systemic sclerosis: a report from the EULAR Scleroderma Trials and Research (EUSTAR) group database. Ann Rheum Dis. 2009;68:856-62.

34. Jaeger VK, Tikly M, Xu D, Siegert E, Hachulla E, Airò P, et al. Racial differences in systemic sclerosis disease presentation: a European scleroderma trials and research group study. Rheumatology (Oxford). 2020;59:1684-94.

35. Saketkoo LA, Escorpizo R, Keen KJ, Fligelstone K, Distler O; EUSTAR. International classification of functioning, disability and health core set construction in systemic sclerosis and other rheumatic diseases: a EUSTAR initiative. Rheumatology (Oxford). 2012;51:2170-6.

36. Maurer B, Graf N, Michel BA, Müller-Ladner U, Czirják L, Denton CP, et al. Prediction of worsening of skin fibrosis in patients with diffuse cutaneous systemic sclerosis using the EUSTAR database. Ann Rheum Dis. 2015;74:1124-31

37. Wu W, Jordan S, Graf N, de Oliveira Pena J, Curram J, Allanore Y, et al. Progressive skin fibrosis is associated with a decline in lung function and worse survival in patients with diffuse cutaneous systemic sclerosis in the European scleroderma trials and research (EUSTAR) cohort. Ann Rheum Dis. 2019;78:648-56.

38. Avouac J, Walker UA, Hachulla E, Riemekasten G, Cuomo G, Carreira $P E$, et al. Joint and tendon involvement predict disease progression in systemic sclerosis: a EUSTAR prospective study. Ann Rheum Dis. 2016;75:103-9.

39. Avouac J, Walker U, Tyndall A, Kahan A, Matucci-Cerinic M, Allanore Y, et al. Characteristics of joint involvement and relationships with systemic inflammation in systemic sclerosis: results from the EULAR scleroderma trial and research group (EUSTAR) database. J Rheumatol. 2010;37:1488-501.

40. Ingegnoli F, Ardoino I, Boracchi P, Cutolo M; EUSTAR co-authors. Nailfold capillaroscopy in systemic sclerosis: data from the EULAR scleroderma trials and research (EUSTAR) database. Microvasc Res. 2013;89:122-8.

41. Blagojevic J, Bellando-Randone S, Abignano G, Avouac J, Cometi L, Czirják $L$, et al. Classification, categorization and essential items for digital ulcer evaluation in systemic sclerosis: a DeSScipher/European scleroderma trials and research group (EUSTAR) survey. Arthritis Res Ther. 2019;21:35.

42. Mihai $C$, Landewé $R$, van der Heijde $D$, Walker UA, Constantin $\mathrm{PI}$, Gherghe Am, et al. Digital ulcers predict a worse disease course in patients with systemic sclerosis. Ann Rheum Dis. 2016;75:681-6.

43. Elhai M, Avouac J, Walker UA, Matucci-Cerinic M, Riemekasten G Airò $\mathrm{P}$, et al. A gender gap in primary and secondary heart dysfunctions in systemic sclerosis: a EUSTAR prospective study. Ann Rheum Dis. 2016;75:163-9.

44. Koumakis E, Wipff J, Dieudé P, Ruiz B, Bouaziz M, Revillod L, et al. TGF $\beta$ receptor gene variants in systemic sclerosis-related pulmonary arterial hypertension: results from a multicentre EUSTAR study of European Caucasian patients. Ann Rheum Dis. 2012;71:1900-3.

45. Adler S, Huscher D, Siegert E, Allanore Y, Cziriák L, DelGaldo F, et al. Systemic sclerosis associated interstitial lung disease individualized immunosuppressive therapy and course of lung function: results of the EUSTAR group. Arthritis Res Ther. 2018;20:17. 
46. Kowal-Bielecka O, Chwiesko-Minarowska S, Bernatowicz PL, Allanore Y, Radstake T, Matucci-Cerinic M, et al. The arachidonate 5-lipoxygenase activating protein gene polymorphism is associated with the risk of scleroderma-related interstitial lung disease: a multicentre European scleroderma trials and research group (EUSTAR) study. Rheumatology (Oxford). 2017;56:844-52.

47. Hoffmann-Vold AM, Allanore Y, Alves M, Brunborg C, Airó P, Ananieva LP, et al. Progressive interstitial lung disease in patients with systemic sclerosis-associated interstitial lung disease in the EUSTAR database. Ann Rheum Dis. 2021;80:219-27.

48. Wipff J, Coriat R, Masciocchi M, Caramaschi P, Derk CT, Hachulla E, et al. Outcomes of Barrett's oesophagus related to systemic sclerosis: a 3-year EULAR Scleroderma Trials and Research prospective follow-up study. Rheumatology (Oxford). 2011:50:1440-4.

49. Ghrénassia E, Avouac J, Khanna D, Derk CT, Distler O, Suliman YA et al. Prevalence, correlates and outcomes of gastric antral vascular ectasia in systemic sclerosis: a EUSTAR case-control study. J Rheumatol. 2014:41:99-105.

50. Sobanski V, Giovannelli J, Allanore Y, Riemekasten G, Airò P, Vettori S, et al. Phenotypes determined by cluster analysis and their survival in the prospective European scleroderma trials and research cohort of patients with systemic sclerosis. Arthritis Rheumatol. 2019;71:1553-70.

51. Foeldvari I, Tyndall A, Zulian F, Müller-Ladner U, Czirjak L, Denton C, et al. Juvenile and young adult-onset systemic sclerosis share the same organ involvement in adulthood: data from the EUSTAR database. Rheumatology (Oxford). 2012;51:1832-7

52. Hügle T, Schuetz P, Daikeler T, Tyndall A, Matucci-Cerinic M, Walker UA, et al. Late-onset systemic sclerosis--a systematic survey of the EULAR scleroderma trials and research group database. Rheumatology (Oxford). 2011;50:161-5.

53. Avouac J, Fransen J, Walker UA, Riccieri V, Smith V, Muller C, et al Preliminary criteria for the very early diagnosis of systemic sclerosis: results of a Delphi consensus study from EULAR scleroderma trials and research group. Ann Rheum Dis. 2011;70:476-81.

54. Minier T, Guiducci S, Bellando-Randone S, Bruni C, Lepri G, Czirják L, et al. Preliminary analysis of the very early diagnosis of systemic sclerosis (VEDOSS) EUSTAR multicentre study: evidence for puffy fingers as a pivotal sign for suspicion of systemic sclerosis. Ann Rheum Dis. 2014;73:2087-93.

55. Jaeger VK, Wirz EG, Allanore $Y$, Rossbach $P$, Riemekasten G Hachulla $E$, et al. Incidences and risk factors of organ manifestations in the early course of systemic sclerosis: a longitudinal EUSTAR study. PLoS One. 2016;11:e0163894.

56. Heijnen IA, Foocharoen C, Bannert B, Carreira PE, Caporali R, Smith V, et al. Clinical significance of coexisting antitopoisomerase I and anticentromere antibodies in patients with systemic sclerosis: a EUSTAR group-based study. Clin Exp Rheumatol. 2013;31 2 Suppl 76:96-102.

57. Rozman B, Cucnik S, Sodin-Semrl S, Czirják L, Varjú C, Distler O, et al. Prevalence and clinical associations of anti-Ku antibodies in patients with systemic sclerosis: a European EUSTAR-initiated multi-centre case-control study. Ann Rheum Dis. 2008;67:1282-6.

58. Lazzaroni MG, Cavazzana I, Colombo E, Dobrota R, Hernandez J, Hesselstrand $\mathrm{R}$, et al. Malignancies in patients with anti-RNA polymerase III antibodies and systemic sclerosis: analysis of the EULAR scleroderma trials and research cohort and possible recommendations for screening. J Rheumatol. 2017;44:639-47.

59. Lazzaroni MG, Marasco E, Campochiaro C, DeVries-Bouwstra J, Gonzalez-Perez MI, Rojas-Serrano J, et al. The clinical phenotype of Systemic Sclerosis patients with anti-PM/Scl antibodies: results from the EUSTAR cohort. Rheumatology (Oxford). 2021;2021:keab152.

60. Schneeberger D, Tyndall A, Kay J, Søndergaard KH, Carreira PE, Morgiel E, et al. Systemic sclerosis without antinuclear antibodies or Raynaud's phenomenon: a multicentre study in the prospective EULAR scleroderma trials and research (EUSTAR) database. Rheumatology (Oxford). 2013:52:560-7.

61. Becker M, Graf N, Sauter R, Allanore Y, Curram J, Denton CP, et al Predictors of disease worsening defined by progression of organ damage in diffuse systemic sclerosis: a European Scleroderma Trials and Research (EUSTAR) analysis. Ann Rheum Dis. 2019:78:1242-8.

62. Hachulla E, Clerson P, Airò P, Cuomo G, Allanore $Y$, Caramaschi $P$, et al. Value of systolic pulmonary arterial pressure as a prognostic factor of death in the systemic sclerosis EUSTAR population. Rheumatology (Oxford). 2015;54:1262-9

63. Wirz EG, Jaeger VK, Allanore Y, Riemekasten G, Hachulla E, Distler O, et al. Incidence and predictors of cutaneous manifestations during the early course of systemic sclerosis: a 10-year longitudinal study from the EUSTAR database. Ann Rheum Dis. 2016;75:1285-92.

64. Tyndall AJ, Bannert B, Vonk M, Airò P, Cozzi F, Carreira PE, et al. Causes and risk factors for death in systemic sclerosis: a study from the EULAR scleroderma trials and research (EUSTAR) database. Ann Rheum Dis. 2010;69:1809-15.

65. Fransen J, Popa-Diaconu D, Hesselstrand R, Carreira P, Valentini G, Beretta L, et al. Clinical prediction of 5-year survival in systemic sclerosis: validation of a simple prognostic model in EUSTAR centres. Ann Rheum Dis. $2011 ; 70: 1788-92$
66. Elhai M, Meune C, Boubaya M, Avouac J, Hachulla E, Balbir-Gurman A et al. Mapping and predicting mortality from systemic sclerosis. Ann Rheum Dis. 2017;76:1897-905.

67. Castellví I, Elhai M, Bruni $C$, Airò $P$, Jordan $S$, Beretta L, et al. Safety and effectiveness of abatacept in systemic sclerosis: the EUSTAR experience. Semin Arthritis Rheum. 2020;50:1489-93

68. Bruni C, Tashkin DP, Steen V, Allanore Y, Distler O, Grotts J, et al. Intravenous versus oral cyclophosphamide for lung and/or skin fibrosis in systemic sclerosis: an indirect comparison from EUSTAR and randomised controlled trials. Clin Exp Rheumatol. 2020; 38 Suppl 125: 161-8.

69. Jordan S, Distler JH, Maurer B, Huscher D, van Laar JM, Allanore Y, et al. Effects and safety of rituximab in systemic sclerosis: an analysis from the European scleroderma trial and research (EUSTAR) group. Ann Rheum Dis. 2015:74:1188-94.

70. Bruni C, Praino E, Guiducci S, Bellando-Randone S, Furst DE, Matucci-Cerinic M. Hydroxychloroquine and joint involvement in systemic sclerosis: preliminary beneficial results from a retrospective case-control series of an EUSTAR center. Joint Bone Spine. 2017;84:747-8.

71. Elhai M, Meunier M, Matucci-Cerinic M, Maurer B, Riemekasten G, Leturcq $T$, et al. Outcomes of patients with systemic sclerosis-associated polyarthritis and myopathy treated with tocilizumab or abatacept: a EUSTAR observational study. Ann Rheum Dis. 2013;72:1217-20.

72. Hudson M, Thombs BD, Steele R, Watterson R, Taillefer S, Baron M, et al. Clinical correlates of quality of life in systemic sclerosis measured with the World Health Organization disability assessment schedule II. Arthritis Rheum. 2008;59:279-84.

73. Levis B, Kwakkenbos L, Hudson M, Baron M, Thombs BD; Canadian Scleroderma Research Group. The association of sociodemographic and objectively-assessed disease variables with fatigue in systemic sclerosis: an analysis of 785 Canadian scleroderma research group registry patients. Clin Rheumatol. 2017;36:373-9.

74. Rockwood MR, MacDonald E, Sutton E, Rockwood K, Baron M; Canadian Scleroderma Research Group. Frailty index to measure health status in people with systemic sclerosis. J Rheumatol. 2014:41:698-705.

75. El-Baalbaki G, Lober J, Hudson M, Baron M, Thombs BD; Canadian Scleroderma Research Group. Measuring pain in systemic sclerosis: comparison of the short-form McGill Pain Questionnaire versus a single-item measure of pain. J Rheumatol. 2011;38:2581-7.

76. Milette K, Hudson M, Körner A, Baron M, Thombs BD; Canadian Scleroderma Research Group. Sleep disturbances in systemic sclerosis: evidence for the role of gastrointestinal symptoms, pain and pruritus. Rheumatology (Oxford). 2013;52:1715-20.

77. Thombs BD, Jewett LR, Kwakkenbos L, Hudson M, Baron M; Canadian Scleroderma Research Group. Major depression diagnoses among patients with systemic sclerosis: baseline and one-month followup. Arthritis Care Res (Hoboken). 2015;67:411-6.

78. Baron M, Hudson M, Steele R; Canadian Scleroderma Research Group. Malnutrition is common in systemic sclerosis: results from the Canadian scleroderma research group database. J Rheumatol. 2009;36:2737-43.

79. Hudson M, Steele R, Lu Y, Thombs BD; Canadian Scleroderma Research Group, Baron M. Work disability in systemic sclerosis. J Rheumatol. 2009:36:2481-6.

80. Hudson M, Steele R, Lu Y, Thombs BD, Panopalis P, Baron M, et al. Clinical correlates of self-reported physical health status in systemic sclerosis. J Rheumatol. 2009:36:1226-9.

81. Baron M, Hudson M, Dagenais M, Macdonald D, Gyger G, El Sayegh T, et al. Relationship between disease characteristics and oral radiologic findings in systemic sclerosis: results from a Canadian oral health study. Arthritis Care Res (Hoboken). 2016:68:673-80.

82. Bernatsky S, Hudson M, Pope J, Markland J, Robinson D, Jones N, et al. Reports of abnormal cervical cancer screening tests in systemic sclerosis. Rheumatology (Oxford). 2009:48:149-51.

83. Levis B, Hudson M, Knafo R, Baron M, Nielson WR, Hill M, et al. Rates and correlates of sexual activity and impairment among women with systemic sclerosis. Arthritis Care Res (Hoboken). 2012;64:340-50.

84. Mansour S, Bonner A, Muangchan C, Hudson M, Baron M, Pope JE, et al. Low socioeconomic status (measured by education) and outcomes in systemic sclerosis: data from the Canadian Scleroderma Research Group. J Rheumatol. 2013:40:447-54

85. Bernatsky S, Hudson M, Panopalis P, Clarke AE, Pope J, Leclercq S, et al. The cost of systemic sclerosis. Arthritis Rheum. 2009;61:119-23.

86. Hoa S, Hudson M, Troyanov Y, Proudman S, Walker J, Stevens W, et al. Single-specificity anti-Ku antibodies in an international cohort of 2140 systemic sclerosis subjects: clinical associations. Medicine (Baltimore). 2016;95:e4713.

87. Sharif R, Fritzler MJ, Mayes MD, Gonzalez EB, McNearney TA Draeger $\mathrm{H}$, et al. Anti-fibrillarin antibody in African American patients with systemic sclerosis: immunogenetics, clinical features, and survival analysis. J Rheumatol. 2011;38:1622-30.

88. Hudson M, Pope J, Mahler M, Tatibouet S, Steele R, Baron M, et al. Clinical significance of antibodies to Ro52/TRIM21 in systemic sclerosis. Arthritis Res Ther. 2012;14:R50. 
89. Mejia Otero C, Assassi S, Hudson M, Mayes MD, Estrada-Y-Martin R Pedroza $\mathrm{C}$, et al. Antifibrillarin antibodies are associated with native North American ethnicity and poorer survival in systemic sclerosis. J Rheumatol. 2017:44:799-805.

90. Hudson M, Luck Y, Stephenson M, Choi MY, Wang M, Baron M, et al. Anti-HMGCR antibodies in systemic sclerosis. Medicine (Baltimore). 2016;95:e5280.

91. Mahler M, You D, Baron M, Taillefer SS, Hudson M; Canadian Scleroderma Research Group, et al. Anti-centromere antibodies in a large cohort of systemic sclerosis patients: comparison between immunofluorescence, CENP-A and CENP-B ELISA. Clin Chim Acta. 2011:412:1937-43.

92. D'Aoust J, Hudson M, Tatibouet S, Wick J; Canadian Scleroderma Research Group, Mahler M, et al. Clinical and serologic correlates of anti-PM/Scl antibodies in systemic sclerosis: a multicenter study of 763 patients. Arthritis Rheumatol. 2014:66 1608-15.

93. Mahler M, Satoh M, Hudson M, Baron M, Chan JY, Chan EK, et al. Autoantibodies to the Rpp25 component of the Th/To complex are the most common antibodies in patients with systemic sclerosis without antibodies detectable by widely available commercial tests. J Rheumatol. 2014;41:1334-43

94. Hudson M, Satoh M, Chan JY, Tatibouet S, Mehra S, Baron M, et al. Prevalence and clinical profiles of 'autoantibody-negative' systemic sclerosis subjects. Clin Exp Rheumatol. 2014;32 6 Suppl 86:S-127-32.

95. Richard N, Hudson M, Wang M, Gyger G, Proudman S, Stevens W, et al. Severe gastrointestinal disease in very early systemic sclerosis is associated with early mortality. Rheumatology (Oxford). 2019;58:636-44.

96. Baron M, Hudson M, Steele R, Lo E; Canadian Scleroderma Research Group. Validation of the UCLA scleroderma clinical trial gastrointestinal tract instrument version 2.0 for systemic sclerosis. J Rheumatol. 2011;38:1925-30.

97. Zhang XJ, Bonner A, Hudson M; Canadian Scleroderma Research Group, Baron M, Pope J. Association of gastroesophageal factors and worsening of forced vital capacity in systemic sclerosis. J Rheumatol. 2013;40:850-8.

98. Steele R, Hudson M, Lo E, Baron M; Canadian Scleroderma Research Group. Clinical decision rule to predict the presence of interstitial lung disease in systemic sclerosis. Arthritis Care Res (Hoboken). 2012; 64:519-24

99. Semalulu T, Rudski L, Huynh T, Langleben D, Wang M; Canadian Scleroderma Research Group, et al. An evidence-based strategy to screen for pulmonary arterial hypertension in systemic sclerosis. Semin Arthritis Rheum. 2020;50:1421-7.

100. Hoa S, Bernatsky S, Steele RJ, Baron M, Hudson M; Canadian Scleroderma Research Group. Association between immunosuppressive therapy and course of mild interstitial lung disease in systemic sclerosis. Rheumatology (Oxford). 2020;59:1108-17.

101. Caron M, Hudson M, Baron M, Nessim S, Steele R; Canadian Scleroderma Research Group. Longitudinal study of renal function in systemic sclerosis. J Rheumatol. 2012;39:1829-34.

102. Jung M, Bonner A, Hudson M, Baron M, Pope JE; Canadian Scleroderma Research Group (CSRG). Myopathy is a poor prognostic feature in systemic sclerosis: results from the Canadian Scleroderma Research Group (CSRG) cohort. Scand J Rheumatol. 2014;43:217-20.

103. Zheng B, Nevskaya T, Baxter CA, Ramey DR, Pope JE, Baron M, et al. Changes in skin score in early diffuse cutaneous systemic sclerosis are associated with changes in global disease severity. Rheumatology (Oxford). 2020:59:398-406

104. Khimdas S, Harding S, Bonner A, Zummer B, Baron M, Pope J, et al. Associations with digital ulcers in a large cohort of systemic sclerosis: results from the Canadian scleroderma research group registry. Arthritis Care Res (Hoboken). 2011:63:142-9.

105. Hudson M, Fritzler MJ, Baron M; Canadian Scleroderma Research Group (CSRG). Systemic sclerosis: establishing diagnostic criteria. Medicine (Baltimore). 2010;89:159-65.

106. Ferdowsi N, Huq M, Stevens W, Hudson M, Wang M, Tay T, et al. Development and validation of the scleroderma clinical trials consortium damage index (SCTC-DI): a novel instrument to quantify organ damage in systemic sclerosis. Ann Rheum Dis. 2019:78:807-16.

107. Bacher A, Mittoo S, Hudson M, Tatibouet S; Canadian Scleroderma Research Group, Baron M. Systemic sclerosis in Canada's North American Native population: assessment of clinical and serological manifestations. J Rheumatol. 2013;40:1121-6.

108. Diab S, Dostrovsky N, Hudson M, Tatibouet S, Fritzler MJ, Baron M, et al Systemic sclerosis sine scleroderma: a multicenter study of 1417 subjects. J Rheumatol. 2014:41:2179-85.

109. Simeón-Aznar CP, Fonollosa-Plá V, Tolosa-Vilella C, Espinosa-Garriga G Ramos-Casals M, Campillo-Grau M, et al. Registry of the Spanish network for systemic sclerosis: clinical pattern according to cutaneous subsets and immunological status. Semin Arthritis Rheum. 2012;41:789-800.

110. Marí-Alfonso B, Simeón-Aznar CP, Guillén-Del Castillo A, Rubio-Rivas M Trapiella-Martínez L, Todolí-Parra JA, et al. Hepatobiliary involvement in systemic sclerosis and the cutaneous subsets: characteristics and survival of patients from the Spanish RESCLE registry. Semin Arthritis Rheum. $2018 ; 47: 849-57$
111. Tolosa-Vilella C, Morera-Morales ML, Simeón-Aznar CP, Marí-Alfonso B, Colunga-Arguelles D, Rubio JL, et al. Digital ulcers and cutaneous subsets of systemic sclerosis: clinical, immunological, nailfold capillaroscopy, and survival differences in the Spanish RESCLE Registry. Semin Arthritis Rheum. 2016;46:200-8

112. Sánchez-Cano D, Ortego-Centeno N, Callejas JL, Plá VF, Ríos-Fernández $\mathrm{R}$, Tolosa-Vilella $\mathrm{C}$, et al. Interstitial lung disease in systemic sclerosis: data from the Spanish scleroderma study group. Rheumatol Int 2018:38:363-74.

113. García-Hernández FJ, Castillo-Palma MJ, Tolosa-Vilella C, Guillén-Del Castillo A, Rubio-Rivas M, Freire M, et al. Pulmonary hypertension in Spanish patients with systemic sclerosis. Data from the RESCLE registry. Clin Rheumatol. 2019;38:1117-24.

114. Pestaña-Fernández M, Rubio-Rivas M, Tolosa-Vilella C, Guillén-Del-Castillo A, Freire M, Vargas-Hitos JA, et al. Longterm efficacy and safety of monotherapy versus combination therapy in systemic sclerosis-associated pulmonary arterial hypertension: a retrospective RESCLE registry study. J Rheumatol. 2020;47:89-98.

115. Pestaña-Fernández M, Rubio-Rivas M, Tolosa-Vilella C Guillén-Del-Castillo A, Colunga-Argüelles D, Argibay $A$, et al. The incidence rate of pulmonary arterial hypertension and scleroderma renal crisis in systemic sclerosis patients with digital ulcers on endothelin antagonist receptors (ERAs) and phosphodiesterase-5 inhibitors (PDE5i). Rheumatology (Oxford). 2021;60:872-80

116. Arandia NI, Simeón-Aznar CP, Del Castillo AG, Argüelles DC, Rubio-Rivas $M$, Martínez LT, et al. Influence of antibody profile in clinical features and prognosis in a cohort of Spanish patients with systemic sclerosis. Clin Exp Rheumatol. 2017;35 Suppl 106:98-105

117. Arandia NI, Espinosa G, Vilella CT, Del Castillo AG, Rivas MR, Freire M, et al. Serodiscordant patients with systemic sclerosis: when antibody does not correspond to skin involvement. Clin Exp Rheumatol. 2020;38 Suppl 125:106-114.

118. Trapiella-Martínez L, Díaz-López JB, Caminal-Montero L, Tolosa-Vilella C Guillén-Del Castillo A, Colunga-Argüelles $\mathrm{D}$, et al. Very early and early systemic sclerosis in the Spanish scleroderma Registry (RESCLE) cohort. Autoimmun Rev. 2017;16:796-802.

119. Simeón-Aznar CP, Fonollosa-Plá V Tolosa-Vilella C, Espinosa-Garriga G Campillo-Grau M, Ramos-Casals M, et al. Registry of the Spanish network for systemic sclerosis: survival, prognostic factors, and causes of death. Medicine (Baltimore). 2015;94:e1728.

120. Rubio-Rivas M, Simeón-Aznar CP, Velasco C, Marí-Alfonso B, Espinosa G Corbella $X$, et al. Changes in the pattern of death of 987 patients with systemic sclerosis from 1990 to 2009 from the nationwide Spanish Scleroderma Registry (RESCLE). Clin Exp Rheumatol. 2017;35 Suppl 106:40-7.

121. Rubio-Rivas M, Corbella X, Pestaña-Fernández M, Tolosa-Vilella C, Guillen-Del Castillo A, Colunga-Argüelles $D$, et al. First clinical symptom as a prognostic factor in systemic sclerosis: results of a retrospective nationwide cohort study. Clin Rheumatol. 2018:37:999-1009.

122. Rubio-Rivas $M$, Corbella $X$, Guillén-Del-Castillo A, Vilella CT, Argüelles DC, Argibay A, et al. Spanish scleroderma risk score (RESCLESCORE) to predict 15-year all-cause mortality in scleroderma patients at the time of diagnosis based on the RESCLE cohort: derivation and internal validation. Autoimmun Rev. 2020;19:102507.

123. Morrisroe K, Huq M, Stevens W, Rabusa C, Proudman SM, Nikpour M, et al. Risk factors for development of pulmonary arterial hypertension in Australian systemic sclerosis patients: results from a large multicenter cohort study. BMC Pulm Med. 2016;16:134.

124. Quinlivan A, Thakkar V, Stevens W, Morrisroe K, Prior D, Rabusa C, et al. Cost savings with a new screening algorithm for pulmonary arterial hypertension in systemic sclerosis. Intern Med J. 2015;45:1134-40.

125. Richard N, Hudson M, Wang M, Gyger G, Proudman S, Stevens W, et al. Severe gastrointestinal disease in very early systemic sclerosis is associated with early mortality. Rheumatology (Oxford). 2019;58:636-44.

126. Fairley JL, Hansen D, Proudman S, Sahhar J, Ngian GS, Walker J, et al. Clinical characteristics and survival in systemic sclerosis-mixed connective tissue disease and systemic sclerosis-overlap syndrome. Arthritis Care Res (Hoboken). 2020;2020:24167.

127. Morrisroe K, Stevens W, Huq M, Prior D, Sahhar J, Ngian GS, et al. Survival and quality of life in incident systemic sclerosis-related pulmonary arterial hypertension. Arthritis Res Ther. 2017;19:122.

128. Morrisroe K, Stevens W, Huq M, Sahhar J, Ngian GS, Zochling J, et al. Validity of the workers productivity and activity impairment questionnaire: specific health problem (WPAI:SHP) in patients with systemic sclerosis. Clin Exp Rheumatol. 2017;35 Suppl 106:130-7

129. Wodkowski M, Hudson M, Proudman S, Walker J, Stevens W, Nikpour M, et al. Clinical correlates of monospecific anti-PM75 and anti-PM100 antibodies in a tri-nation cohort of 1574 systemic sclerosis subjects. Autoimmunity. 2015;48:542-51.

130. Nikpour M, Hissaria P, Byron J, Sahhar J Micallef M, Paspaliaris W, et al. Prevalence, correlates and clinical usefulness of antibodies to RNA polymerase III in systemic sclerosis: a cross-sectional analysis of data from an Australian cohort. Arthritis Res Ther. 2011:13:R211.

131. Patel S, Morrisroe K, Proudman S, Hansen D, Sahhar J, Sim MR, et al. Occupational silica exposure in an Australian systemic sclerosis cohort. Rheumatology (Oxford). 2020;59:3900-5. 
132. Dougherty DH, Kwakkenbos L, Carrier ME, Salazar G, Assassi S, Baron $M$, et al. The scleroderma patient-centered intervention network cohort: baseline clinical features and comparison with other large scleroderma cohorts. Rheumatology. 2018;57:1623-31.

133. Becetti K, Kwakkenbos L, Carrier ME, Gordon JK, Nguyen JT, Mancuso CA, et al. Physical or occupational therapy use in systemic sclerosis: a scleroderma patient-centered intervention network cohort study. J Rheumatol. 2019;46:1605-13.

134. Levis AW, Harel D, Kwakkenbos L, Carrier ME, Mouthon L, Poiraudeau S, et al. Using optimal test assembly methods for shortening patient-reported outcome measures: development and validation of the cochin hand function scale-6: a scleroderma patient-centered intervention network cohort study. Arthritis Care Res (Hoboken). 2016;68:1704-13.

135. Kwakkenbos L, Cumin J, Carrier ME, Bartlett SJ, Malcarne VL, Mouthon L, et al. Factors associated with patient-reported likelihood of using online self-care interventions: a scleroderma patient-centered intervention network (SPIN) cohort study. BMJ Open. 2019;9:e029542.

136. Sommer SJ, Harel D, Kwakkenbos L, Carrier ME, Gholizadeh S, Gottesman $\mathrm{K}$, et al. Assessing differential item functioning for the social appearance anxiety scale: a scleroderma patient-centred intervention network (SPIN) cohort study. BMJ Open 2020;10:e037639.

137. Thombs BD, Kwakkenbos L, Henry RS, Carrier ME, Patten S, Harb S, et al. Changes in mental health symptoms from pre-COVID-19 to COVID-19 among participants with systemic sclerosis from four countries: a scleroderma patient-centered intervention network (SPIN) cohort study. J Psychosom Res. 2020;139:110262.

138. Shanmugam VK, Frech TM, Steen VD, Hummers LK, Shah AA Bernstein EJ, et al. Collaborative national quality and efficacy registry (CONQUER) for scleroderma: outcomes from a multicenter US-based systemic sclerosis registry. Clin Rheumatol. 2020;39:93-102.

139. Morgan ND, Shah AA, Mayes MD, Domsic RT, Medsger TA Jr., Steen VD, et al. Clinical and serological features of systemic sclerosis in a multicenter African American cohort: analysis of the genome research in African American scleroderma patients clinical database. Medicine (Baltimore) 2017:96:e8980.

140. Ferri C, Giuggioli D, Guiducci S, Lumetti F, Bajocchi G, Magnan L, et al. Systemic sclerosis progression investigation (SPRING) Italian registry: demographic and clinico-serological features of the scleroderma spectrum. Clin Exp Rheumatol. 2020;38 Suppl 125:S40-7.

141. Morrisroe K, Hudson M, Baron M, de Vries-Bouwstra J, Carreira PE, Wuttge DM, et al. Determinants of health-related quality of life in a multinational systemic sclerosis inception cohort. Clin Exp Rheumatol 2018;36 Suppl 113:53-60.

142. Hachulla E, Gressin V, Guillevin L, Carpentier P, Diot E, Sibilia J, et al. Early detection of pulmonary arterial hypertension in systemic sclerosis: a French nationwide prospective multicenter study. Arthritis Rheum. 2005;52:3792-800.

143. Humbert M, Sitbon O, Chaouat A, Bertocchi M, Habib G, Gressin V, et al. Pulmonary arterial hypertension in France: results from a national registry. Am J Respir Crit Care Med. 2006;173:1023-30.

144. Hachulla E, de Groote P, Gressin V, Sibilia J, Diot E, Carpentier P, et al. The three-year incidence of pulmonary arterial hypertension associated with systemic sclerosis in a multicenter nationwide longitudinal study in France. Arthritis Rheum. 2009;60:1831-9.
145. Humbert M, Sitbon O, Yaici A, Montani D, O'Callaghan DS, Jaïs X, et al. Survival in incident and prevalent cohorts of patients with pulmonary arterial hypertension. Eur Respir J. 2010;36:549-55.

146. Sitbon O, Benza RL, Badesch DB, Barst RJ, Elliott CG, Gressin V, et al. Validation of two predictive models for survival in pulmonary arterial hypertension. Eur Respir J. 2015;46:152-64.

147. Hachulla E, Carpentier P, Gressin V, Diot E, Allanore Y, Sibilia J, et al. Risk factors for death and the 3-year survival of patients with systemic sclerosis: the French ItinérAIR-Sclérodermie study. Rheumatology (Oxford). 2009;48:304-8.

148. Hinchcliff M, Fischer A, Schiopu E, Steen VD; PHAROS Investigators. Pulmonary hypertension assessment and recognition of outcomes in scleroderma (PHAROS): baseline characteristics and description of study population. J Rheumatol. 2011;38:2172-9.

149. Hsu VM, Chung L, Hummers LK, Shah A, Simms R, Bolster M, et al. Risk factors for mortality and cardiopulmonary hospitalization in systemic sclerosis patients at risk for pulmonary hypertension, in the PHAROS registry. J Rheumatol. 2019;46:176-83.

150. Hsu VM, Chung L, Hummers LK, Wigley F, Simms R, Bolster M, et al. Development of pulmonary hypertension in a high-risk population with systemic sclerosis in the pulmonary hypertension assessment and recognition of outcomes in scleroderma (PHAROS) cohort study. Semin Arthritis Rheum. 2014;44:55-62.

151. Kolstad KD, Li S, Steen V, Chung L; PHAROS Investigators. Long-term outcomes in systemic sclerosis-associated pulmonary arterial hypertension from the pulmonary hypertension assessment and recognition of outcomes in scleroderma registry (PHAROS). Chest. 2018;154:862-71.

152. Bae S, Saggar R, Bolster MB, Chung L, Csuka ME, Derk C, et al. Baseline characteristics and follow-up in patients with normal haemodynamics versus borderline mean pulmonary arterial pressure in systemic sclerosis: results from the PHAROS registry. Ann Rheum Dis. 2012;71:1335-42.

153. Lammi MR, Saketkoo LA, Gordon JK, Steen VD. Changes in hemodynamic classification over time are common in systemic sclerosis-associated pulmonary hypertension: insights from the PHAROS cohort. Pulm Circ. 2018;8:2045893218757404.

154. Hinchcliff M, Khanna S, Hsu VM, Lee J, Almagor O, Chang RW, et al. Survival in systemic sclerosis-pulmonary arterial hypertension by serum autoantibody status in the pulmonary hypertension assessment and recognition of outcomes in scleroderma (PHAROS) registry. Semin Arthritis Rheum. 2015;45:309-14.

155. Chung L, Fairchild RM, Furst DE, Li S, Alkassab F, Bolster MB, et al. Utility of B-type natriuretic peptides in the assessment of patients with systemic sclerosis-associated pulmonary hypertension in the PHAROS registry. Clin Exp Rheumatol. 2017;35 Suppl 106:106-13.

156. Fischer A, Swigris JJ, Bolster MB, Chung L, Csuka ME, Domsic R, et al. Pulmonary hypertension and interstitial lung disease within PHAROS: impact of extent of fibrosis and pulmonary physiology on cardiac haemodynamic parameters. Clin Exp Rheumatol. 2014;32 6 Suppl 86:S109-14.

157. Lammi MR, Mathai SC, Saketkoo LA, Domsic RT, Bojanowski C, Furst $\mathrm{DE}$, et al. Association between initial oral therapy and outcomes in systemic sclerosis-related pulmonary arterial hypertension. Arthritis Rheumatol. 2016;68:740-8. 